ljtihad: Jurnal Wacana Hukum Islam dan Kemanusiaan

Vol. 19, No. 1 (2019), pp. 53-66, doi : 10.18326/ijtihad.v19i1.53-66

\title{
An investigation of the relationship between sukuk and the performance of banks of Pakistan
}

\author{
Sitara Bibi
}

Department of Management Sciences, The Islamia University of Bahawalpur, Pakistan

E-mail: rameenawan77788@gmail.com

\section{Fatima Mazhar}

Department of Management Sciences, Govt Sadiq College Women University Bahawalpur, Pakistan E-mail: fatima.mazhar@gscwu.edu.pk

DOI: 10.18326/ijtihad.v19i1.53-66

This study investigated the relationship among Islamic bonds (sukuk) and the performance of Islamic Banks (IB's) of Pakistan for the period of 2008-2017 by using panel data analysis. The study used two stages approach. At the first stage, the profitability and liquidity of banks had been measured by calculating financial ratios. These ratios were than further used in regression analysis to examine whether a relationship exists between sukuk and the bank's profitability and liquidity. The study found a significant positive relationship among sukuk and the liquidity of IB's. While, the results showed significant but negative relationship between sukuk and profitability of IB's. Based on the findings of the study, it coul be concluded that sukuk has an important role in enhancing the liquidity of IB's but it has adverse impact on the profitability of IB's of Pakistan. Thus, the emergence of sukuk market may pose threats to the profitability of the IB's of Pakistan.

Penelitian ini menyelidiki hubungan antara obligasi Islam (sukuk) dan kinerja Islamic Bank (IB) di Pakistan untuk periode 2008-2017dengan menggunakan analisis data panel. Penelitian ini menggunakan pendekatan dua tahap. Pada tahap pertama, profitabilitas dan likuiditas bank telah diukur dengan menghitung rasio keuangan. Rasio ini kemudian digunakan dalam analisis regresi untuk menguji apakah ada hubungan antara sukuk dan profitabilitas dan likuiditas bank. Studi ini menemukan hubungan positif yang signifikan antara sukuk dan likuiditas IB. Sementara, hasilnya menunjukkan hubungan yang signifikan tetapi negatif antara sukuk dan profitabilitas IB. Berdasarkan 
ljtihad: Jurnal Wacana Hukum Islam dan Kemanusiaan, Volume 19, No. 1, Juni 2019: 53-66

temuan penelitian, dapat disimpulkan bahwa sukuk memiliki peran penting dalam meningkatkan likuiditas IB tetapi memiliki dampak buruk pada profitabilitas IB di Pakistan. Dengan demikian, munculnya pasar sukuk dapat menimbulkan ancaman terhadap profitabilitas IB di Pakistan.

Key words: sukuk, banks, profitability, liquidity

\section{Introduction}

The origin of sukuk was firstly introduced by Malaysia in 2002 when it issued first Islamic bond with the name of government-backed sukuk (Braima, 2017:85). In May 2003, it was officially defined by Accounting and Auditing Organization for Islamic Financial Institutions (AAOIFI) as the certificates having equal value which represent undivided share's ownership in tangible assets as well as legal rights and services (Mohamed, Masih, \& Bacha, 2015:233). It started growing in 2005 when there was an increase in the prices of oil all over the world (Reuters, 2016).

The word "sukuk" also known as Islamic bond or Islamic investment certificate is drawn from Arabic word "sake." meaning a Shariah compliant bond or security that enables the investors to avoid investment in conventional bonds or securities (Zulkhibri, 2015:237). They are good for the investors who avoid investing in conventional securities because of religious restrictions (Yesuf, 2016). Sukuk are basically documents of debt that governments and organizations issue to borrow a certain amount of money from bondholders (Elhaj, Muhamed, \& Ramli, 2015). It can be defined as a financial instrument that helps the market players to get a large amount of capital or cash from the investors in the market through the development of various structures of sukuk (Razak, Saiti, \& Dinc, 2018). They have the characteristics which differentiate them from conventional securities (Lahsasna, Hassan, \& Ahmad, 2018).

Now, sukuk has become one of the strongest segments and is considered an attractive financial instrument for the Islamic financial institutions. They are becoming important financial instruments not only for the Muslim but also for the non- Muslim countries of the world (Zawya, 2013:22). Both the Muslim and non-Muslim countries such as Nigeria, South Africa in Africa, Morocco, France, Kazakhstan in Central Asia, United Kingdom in Europe and Brunei in East Asia are becoming more interested in using sukuk as an 
alternative of conventional bonds to raise their capital/finance. For this purpose they have revised their regulations and laws to make it possible the sukuk issuance. Some other countries are also working to make it easy to issue Islamic bonds (Zulkhibri, 2015:237); (Ahmed, Islam, Yousif, \& Alabdullah, 2014). The fund management industry including Islamic Capital Market is positively influenced by increase in the use of sukuk for capital rising (Alam, Hassan, \& Haque, 2013:22).

One main reason for rapid emergence of sukuk market is that it is a Shariah compliant security which is the main feature of the sukuk (Ahmed, Islam, Yousif, \& Alabdullah, 2014). Other main reason is that sukuk are the major source of competitive advantage as they have targeted the market segment which is not targeted by rivals yet (Ahmad, Daud, \& Kefeli, 2012:127). Sukuk are considered an important tool to manage the firm's liquidity and the fresh fund's mobilization which is another major reason of the emergence of sukuk (Vishwanth \& Azmi, 2009:58).

In Pakistan, it was issued for the first time in 2005 when Pakistan issued an international sovereign sukuk of 600 million. This sukuk offered semiannually floating rate of return and was based on Master Iajra agreement. While, it was issued in Pakistan's domestic sukuk market for the first time in 2006. Since then Pakistan has issued sukuk with the amount of 695 billion. The sukuk market has helped the IB's of Pakistan in diversifying their asset mix as it provided them an attractive instrument for investment in addition of improving IB's earnings as well as profitability (Alvi, et al., 2014).

Despite the rapid emergence of sukuk issuance in global market, there are limited researches conducted on this topic (Smaoui \& Khawaja, 2016:1501) particularly in Pakistan. This research is one of the few academic researches on the sukuk in context of Pakistan. This study has been designed to uncover the relationship between Islamic bonds (sukuk) and the performance of the IB's of Pakistan.

To investigate the relationship between sukuk and bank's performance, the following two questions have been developed; First, whether the is any relationship between sukuk and bank's profitability, and second, whether there is any relationship between sukuk and liquidity. This is the first study which investigates the relationship among Islamic securitization and the bank's profitability and liquidity in context of Pakistan. Said, (2011:65) 
investigated the impact of using sukuk on the Islamic bank's performance during the period of financial crises of 2007-2008 by taking the profitability of Malaysian's banking sector. His investigation found no significant impact of sukuk on the profitability of Malaysian banks. Razak, Saiti, \& Dinc, (2018) disccused the pricing structures of various sukuk and their critical assessment. Smaoui, Mimouni, \& Temimi, (2017) investigated the impact of the financial development of a country like effect of banking system, stock market and bond market on the issuance of sukuk. Smaoui \& Khawaja, (2016:1501) studied the financial, developmental, macroeconomics and institutional determinants of sukuk markets and found a significant impact of all these factors on the sukuk market.

Nagano, (2016:142) conducted a study on the factors that promote a bank borrower to issue sukuk instead of issuing a conventional debt security by taking the banks of Malaysia and Indonesia as a sample for the study and concluded that firms use sukuk as an intermediate funding market when there is a larger funding demand to borrow from the banks and the information asmetry is also high to access the conventional debt. Ahmed, Islam, Yousif, \& Alabdullah, (2014) worked on the significance of pricing and rating mechanism of Islamic bonds. According to them sukuk are going to become more comprehensive as well as credible financial instruments just because of their compliance with Islamic principles. This will promote the economic growth too. The current study is aimed to investigate the relationship between Islamic bonds and Islamic bank's profitability and liquidity using a sample of IB's of Pakistan for the year 2008-2017. This study is intended to contribute to the growing literature on Islamic securitization by testing the following hypothesis;

$\mathrm{H}_{1}$ There is a significant positive relationship between sukuk and bank's profitability. $\mathrm{H}_{2}$ There is a significant positive relationship between sukuk and bank's liquidity.

The hypothesis mentioned above is illustrated in figure 1 shown below; 
Figure 1. Conceptual Framework

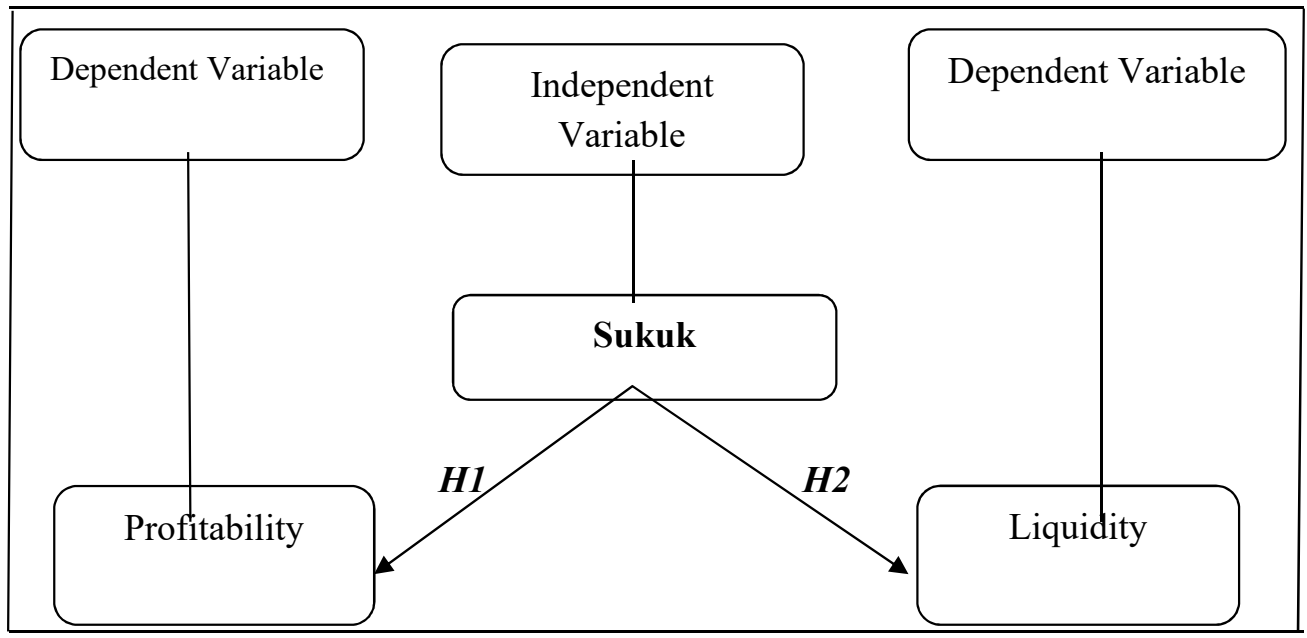

\section{Data and methodology:}

This study is descriptive in nature which follows quantitative research design. In this study, we investigated the relationship between sukuk and performance of the banks of Pakistan by using the panel regression analysis. Statistical package for social sciences has been used for the data analysis. The full-fledged IB's of Pakistan that are using sukuk have been selected as a sample for the study. The list of selected banks is given below;

Table 1. List of Full-Fledged IB's of Pakistan that are Using Sukuk and their Background Information

\begin{tabular}{ccccc}
\hline Sr.no & Name of the Bank & $\begin{array}{c}\text { Year of } \\
\text { Entry }\end{array}$ & $\begin{array}{c}\text { No of } \\
\text { Branches }\end{array}$ & \multicolumn{1}{c}{ Description } \\
\hline i. & Bank Islami limited & 2006 & 37 & $\begin{array}{l}\text { The } 2^{\text {nd }} \text { worldwide bank with biometric } \\
\text { technology in ATM's, started its operation in } \\
\text { Pakistan by April 2006. }\end{array}$ \\
\hline ii. $\quad$ Meezan Bank limited & 2002 & 113 & $\begin{array}{l}1^{\text {st }} \text { Islamic bank of Pakistan to which the SBP } \\
\text { issued first Islamic banking license in 2002. }\end{array}$ \\
\hline iii. $\quad$ Al-Baraka Bank limited & 2004 & 20 & $\begin{array}{l}\text { It is the 2 } 2^{\text {nd }} \text { oldest Islamic bank of Pakistan. It } \\
\text { is operating with the help of the Bahrain- based } \\
\text { Al-Baraka Banking Group (ABG) which is } \\
\text { known as a key contributor in investment and } \\
\text { treasury services of Islamic banking. }\end{array}$ \\
\hline
\end{tabular}


Ijtihad: Jurnal Wacana Hukum Islam dan Kemanusiaan, Volume 19, No. 1, Juni 2019: 53-66

\begin{tabular}{|c|c|c|c|c|}
\hline Sr.no & Name of the Bank & $\begin{array}{l}\text { Year of } \\
\text { Entry }\end{array}$ & $\begin{array}{c}\text { No of } \\
\text { Branches }\end{array}$ & Description \\
\hline iv. & Dubai Islamic Bank limited & 2006 & 20 & $\begin{array}{l}\text { Basically, this bank is the subsidiary of DIB } \\
\text { which is headquartered in the UAE. It is the IB } \\
\text { of Pakistan which has introduced first Islamic } \\
\text { visa debit card. One of the major aims of the } \\
\text { bank is to bring the foreign investors in the } \\
\text { country. }\end{array}$ \\
\hline v. & $\begin{array}{l}\text { Dawood Islamic Bank lim- } \\
\text { ited }\end{array}$ & 2007 & 14 & $\begin{array}{l}\text { It is aimed to focus on importers and exporters } \\
\text { segments that avoid the bank financing because } \\
\text { of the threat of breaching Islamic laws defined } \\
\text { by Holy Quran and Sunnah. }\end{array}$ \\
\hline vi. & $\begin{array}{l}\text { Emirates Global Islamic } \\
\text { Bank limited }\end{array}$ & 2007 & 24 & $\begin{array}{l}\text { This bank is basically, backed by the united } \\
\text { Arab Emirates and Saudi Arabia's investors. } \\
\text { It is operating all over the Pakistan with } 24 \\
\text { branches. }\end{array}$ \\
\hline
\end{tabular}

All this data has been extracted from the website of State Bank of Pakistan (SBP) using the reports published by SBP. One of them is Islamic banking review 2003 to 2007. The background information about the sample of the study has been extracted from above mentioned publication of SBP (Akhtar, 2007).

We extracted the data through secondary sources using the published annual financial statements for the year of 2008-2017 of the selected banks and thus it is cross sectional study which covers the range of years. It may also consider time series data. The annual statements have been taken from the official websites of the selected banks. Financial ratios of selected banks have been used for the purpose of analysis as according to Said (2011:65) financial ratio analysis is considered most convenient as well as beneficial instrument to measure the firm's performance. The total value of sukuk has been calculated as a percentage of total assets of the selected banks. This value was further used in regression analysis.

Profitability and liquidity of the selected banks have been used as an indicator of bank's performance in which profitability is measure by net profit margin, return on assets, return on equity and return on capital employed and liquidity is measured by current ratio, net loan to total deposit ratio and net loans to total assets ratio while the value of sukuk has been used as an independent variable of the study. An explanation of the variables used in the study is given below. 
An Investigation of the Relationship between Sukuk and the Performance of banks...(Sitara Bibi)

Table 2. Description of Variables

\begin{tabular}{|c|c|c|c|}
\hline Variable type & Financial Ratios & Legend & How calculated \\
\hline \multicolumn{4}{|c|}{ - Profitability } \\
\hline \multirow{8}{*}{ variable: } & Net profit margin & NPM & (Net profit/Net sales)* 100 \\
\hline & Return on asset & $\mathrm{ROA}$ & Net income/Total assets \\
\hline & Return on equity & ROE & Net income/Shareholder's equity \\
\hline & Return on capital employed & ROCE & EBIT/ Capital employed \\
\hline & \multicolumn{3}{|l|}{$\cdot$ Liquidity } \\
\hline & Current ratio & CR & Current assets/Current liabilities \\
\hline & Net loans to total deposits & NLTD & Net loans / deposits \\
\hline & Net loans total assets & NLTA & Total liabilities / Total assets \\
\hline Independent & - Sukuk & NA & Sukuk/Total assets \\
\hline variable: & & & \\
\hline
\end{tabular}

Source: (Said, 2011); (G’itman \& Zutter, 2012); (Khan \& Siddiqui, 2018); (Bibi \& Mazhar, 2019)

\section{Data analysis and discussions:}

\section{Descriptive statistics:}

Table 3 states the descriptive analysis of the sample for the study which includes Net profit margin. Return on assets, Return on capital employed, Return on equity, Current ratio, Net loans to total assets, Net loans to total deposits and the value of sukuk. The values of skewness and kurtosis in column 8 and 9 respectively shows the normality of data used in the study as the values of Skewness and kurtosis lie between the range of $\pm 1 \& \pm 3$. Sekaran, (2003) in her book entitled Research Methods for Business stated that the data would be considered normal if the values of Skewness and kurtosis fall in a range of $\pm 1 \& \pm 3$. Thus, the normality of the data has been confirmed through the descriptive statistics.

Table 3. Descriptive Statistics

\begin{tabular}{rlrrrrrrr}
\hline Variables & Ratios & N & Minimum & Maximum & \multicolumn{1}{c}{ Mean } & St. D & Skewness & Kurtosis \\
\hline Profitability & NPM & 60 & 13.94 & 28.79 & 20.5053 & 2.73684 & -1.460 & 1.576 \\
& ROA & 60 & 0.71 & 2.89 & 1.3827 & 0.63365 & 0.224 & -1.543 \\
& ROE & 60 & 19.02 & 25.04 & 22.0032 & 1.63348 & -1.116 & 0.036 \\
& ROEC & 60 & 1.40 & 1.98 & 1.6973 & 0.15002 & 1.043 & 1.953 \\
\hline
\end{tabular}


Ijtihad: Jurnal Wacana Hukum Islam dan Kemanusiaan, Volume 19, No. 1, Juni 2019: 53-66

\begin{tabular}{llrrrrrrr}
\hline Variables & Ratios & N & Minimum & Maximum & Mean & St. D & Skewness & Kurtosis \\
\hline Liquidity & CR & 60 & 1.00 & 3.07 & 1.7655 & 0.61418 & 1.665 & -1.611 \\
& NLTA & 60 & 0.45 & 1.00 & 0.7507 & 0.15177 & -0.128 & -0.167 \\
& NLTD & 60 & 0.00 & 0.67 & 0.0387 & 0.09880 & -2.140 & 2.711 \\
\hline Sukuk & Sukuk & 60 & 0.49 & 36.89 & 21.3277 & 12.00884 & 2.384 & 1.840 \\
\hline
\end{tabular}

\section{Correlation analysis:}

Table 4 explores the correlation relationship among Net profit margin, Return on assets, Return on equity, Return on capital employed, Net loans to total assets, Net loans to total deposits and the sukuk. The results show the correlation between sukuk and bank's liquidity is statistically significant at the level of 0.01 or below 0.01 . These results are in predicted directions and show a significant and positive relationship between sukuk and bank's liquidity.

This means that an increase in the value of sukuk leads to the increase in the bank's liquidity. This is due to significant positive correlation between sukuk and the liquidity of IB's. While at the same time, the results show a significant but negative relationship between sukuk and bank's profitability. This means that the profitability of banks is negatively affected by any change in the value of sukuk.

Table 4. Correlation Matrix

\begin{tabular}{|c|c|c|c|c|c|c|c|c|c|}
\hline & & NPM & ROA & ROE & ROEC & CR & NLTA & NLTD & Sukuk \\
\hline \multirow[t]{3}{*}{ NPM } & $\begin{array}{l}\text { Pearson } \\
\text { correlation }\end{array}$ & 1 & $-0.620^{* *}$ & $-0.419 * *$ & $-0.343^{* *}$ & $0.508^{* *}$ & $0.482^{* *}$ & $0.649 * *$ & $0.795^{* *}$ \\
\hline & Sig ( 2 tailed) & & 0.000 & 0.001 & 0.007 & 0.000 & 0.000 & 0.000 & 0.000 \\
\hline & $\mathrm{N}$ & 60 & 60 & 60 & 60 & 60 & 60 & 60 & 60 \\
\hline \multirow[t]{3}{*}{ ROA } & $\begin{array}{l}\text { Pearson } \\
\text { correlation }\end{array}$ & $-0.620 * *$ & 1 & $-0.590 * *$ & $-0.497 * *$ & $0.416^{* *}$ & $0.680 * *$ & 0.821 ** & $0.649 * *$ \\
\hline & Sig ( 2 tailed) & 0.000 & & 0.000 & 0.000 & 0.001 & 0.002 & 0.000 & 0.000 \\
\hline & $\mathrm{N}$ & 60 & 60 & 60 & 60 & 60 & 60 & 60 & 60 \\
\hline \multirow[t]{3}{*}{ ROE } & $\begin{array}{l}\text { Pearson } \\
\text { correlation }\end{array}$ & $-0.419 * *$ & $-0.590 * *$ & 1 & $-0.414^{* *}$ & $0.476^{* *}$ & $0.396 * *$ & $0.890 * *$ & $0.438^{* *}$ \\
\hline & Sig ( 2 tailed) & 0.001 & 0.000 & & 0.001 & 0.000 & 0.005 & 0.000 & 0.003 \\
\hline & $\mathrm{N}$ & 60 & 60 & 60 & 60 & 60 & 60 & 60 & 60 \\
\hline \multirow[t]{3}{*}{ ROEC } & $\begin{array}{l}\text { Pearson } \\
\text { correlation }\end{array}$ & $-0.343^{* *}$ & $-0.497 * *$ & $-0.414^{* *}$ & 1 & $0.412^{* *}$ & 0.721 ** & 0.871 ** & 0.921 ** \\
\hline & $\operatorname{Sig}$ ( 2 tailed) & 0.007 & 0.000 & 0.001 & & 0.000 & 0.000 & 0.000 & 0.000 \\
\hline & $\mathrm{N}$ & 60 & 60 & 60 & 60 & 60 & 60 & 60 & 60 \\
\hline
\end{tabular}


An Investigation of the Relationship between Sukuk and the Performance of banks...(Sitara Bibi)

\begin{tabular}{|c|c|c|c|c|c|c|c|c|c|}
\hline & & NPM & ROA & ROE & ROEC & CR & NLTA & NLTD & Sukuk \\
\hline \multirow[t]{3}{*}{ CR } & $\begin{array}{l}\text { Pearson } \\
\text { correlation }\end{array}$ & $0.508^{* *}$ & $0.416^{* *}$ & $0.476^{* *}$ & $0.412^{* *}$ & 1 & $0.437 * *$ & $0.547 * *$ & $0.454 * *$ \\
\hline & Sig ( 2 tailed) & 0.000 & 0.001 & 0.000 & 0.000 & & 0.000 & 0.000 & 0.000 \\
\hline & $\mathrm{N}$ & 60 & 60 & 60 & 60 & 60 & 60 & 60 & 60 \\
\hline \multirow[t]{3}{*}{ NLTA } & $\begin{array}{l}\text { Pearson } \\
\text { correlation }\end{array}$ & $0.482^{* *}$ & $0.680 * *$ & $0.396^{* *}$ & $0.721 * *$ & $0.437 * *$ & 1 & $0.715^{* *}$ & $0.614^{* *}$ \\
\hline & Sig ( 2 tailed) & 0.000 & 0.002 & 0.005 & 0.000 & 0.000 & & 0.000 & 0.000 \\
\hline & $\mathrm{N}$ & 60 & 60 & 60 & 60 & 60 & 60 & 60 & 60 \\
\hline \multirow[t]{3}{*}{ NLTD } & $\begin{array}{l}\text { Pearson } \\
\text { correlation }\end{array}$ & 0.649 ** & $0.821 * *$ & $0.890^{* *}$ & $0.871^{* *}$ & $0.547 * *$ & $0.715^{* *}$ & 1 & $0.494 * *$ \\
\hline & $\operatorname{Sig}$ ( 2 tailed) & 0.000 & 0.000 & 0.000 & 0.000 & 0.000 & 0.000 & & 0.000 \\
\hline & $\mathrm{N}$ & 60 & 60 & 60 & 60 & 60 & 60 & 60 & 60 \\
\hline \multirow[t]{3}{*}{ Sukuk } & $\begin{array}{l}\text { Pearson } \\
\text { correlation }\end{array}$ & $0.795^{* *}$ & $0.649 * *$ & $0.438^{* *}$ & $0.921 * *$ & $0.454 * *$ & $0.614 * *$ & $0.494^{* *}$ & 1 \\
\hline & Sig ( 2 tailed) & 0.000 & 0.000 & 0.003 & 0.000 & 0.000 & 0.000 & 0.000 & \\
\hline & $\mathrm{N}$ & 60 & 60 & 60 & 60 & 60 & 60 & 60 & 60 \\
\hline
\end{tabular}

**. Correlation is significant at the 0.01 level (2 tailed).

Regression analysis:

Table 5. Regression Results of Criterion Variable Profitability

\begin{tabular}{clcccccc}
\hline Sr.no & Variables & R-Square & $\begin{array}{c}\text { Adjusted } \\
\text { R-Square }\end{array}$ & P-Value & $\begin{array}{c}\text { Standardized } \\
\boldsymbol{\beta}\end{array}$ & F-Value & T-Value \\
\hline 1. & NPM & 0.460 & 0.395 & 0.012 & 0.509 & 18.765 & -2.570 \\
2. & ROA & 0.510 & 0.489 & 0.017 & 0.488 & 14.037 & -3.484 \\
3. & ROE & 0.498 & 0.429 & 0.032 & 0.375 & 12.764 & -2.821 \\
4. & ROCE & 0.567 & 0.474 & 0.051 & 0.497 & 23.050 & -2.317 \\
\hline
\end{tabular}

Dependent variables: NPM, ROA, ROE, ROCE

Predictor (Constant): Sukuk

The results in table 5 show that sukuk has significant but negative impact on the profitability of IB's. The value R- Square shows that 46\% changes in NPM is observed due to the change in sukuk. Similarly, 51\% change in ROA, 49.8\% change in ROE and $56.7 \%$ change in ROCE is observed by changes in independent variable. The significant P-Values of regression model are at the level of 0.05 or below 0.05 which show that the impact of sukuk on profitability is significant. The negative T- Values of the model show that the impact of IV on DV is negative. The F-Values in the model show the significance 
ljtihad: Jurnal Wacana Hukum Islam dan Kemanusiaan, Volume 19, No. 1, Juni 2019: 53-66

of the model. Thus, overall regression model in table: 05 is statistically fit which shows a significant negative relationship among sukuk and bank's profitability.

Table 6. Regression Results of Criterion Variable Liquidity

\begin{tabular}{clrrrrrr}
\hline Sr.no & Variables & R-Square & Adjusted R-Square & P-Value & Standardized $\beta$ & F-Value & T-Value \\
\hline 1. & CR & 0.591 & 0.562 & 0.000 & 0.592 & 16.49 & 3.213 \\
2. & NLTA & 0.652 & 0.616 & 0.000 & 0.641 & 12.59 & 3.270 \\
3. & NLTD & 0.509 & 0.487 & 0.000 & 0.539 & 21.48 & 2.283 \\
\hline
\end{tabular}

Dependent variables: CR, NLTA, NLTD

Predictor (Constant): Sukuk.

The results in table 6 show that sukuk has significant positive impact on the liquidity of IB's. The value R- Square shows that $59.2 \%$ changes in CR is shown due to the change in sukuk. Similarly, $65.2 \%$ change in NLTA and $50.9 \%$ change in NLTD is observed by changes in independent variable. The significant P-Values of regression model are at the level of 0.000 which show that the impact of sukuk on liquidity is significant. The positive T- Values of the model show that the impact of IV on DV in positive. The F-Values in the model show the significance of the model. Thus, overall regression model in table 6 is statistically fit and shows a significant positive relationship among sukuk and bank's liquidity.

\section{Results of hypotheses testing:}

The results of correlation matrix have helped to prove the assumptions of the study. The explanation of the working hypothesis of the study is given below in table 7 .

Table 7. Results of the Assumptions of the Study

\begin{tabular}{|c|c|c|c|c|}
\hline Sr.no & Hypothesis & Tool used & Results & Description \\
\hline $\mathrm{H}_{1}$ & $\begin{array}{l}\text { There is a significant } \\
\text { positive relationship } \\
\text { between Sukuk and bank's } \\
\text { profitability. }\end{array}$ & Regression & Rejected & $\begin{array}{l}\text { The results of the regression } \\
\text { shows that issuance of Islamic } \\
\text { bonds is negatively correlated } \\
\text { with the profitability of IB's. } \\
\text { This means that increase in } \\
\text { issuance of Islamic bonds } \\
\text { have adverse impact on the } \\
\text { profitability of the IB's of } \\
\text { Pakistan. }\end{array}$ \\
\hline
\end{tabular}


An Investigation of the Relationship between Sukuk and the Performance of banks...(Sitara Bibi)

\begin{tabular}{|c|c|c|c|c|}
\hline $\mathbf{H}_{2}$ & $\begin{array}{l}\text { There is a significant } \\
\text { positive relationship } \\
\text { between Sukuk and bank's } \\
\text { liquidity. }\end{array}$ & Regression & Accepted & $\begin{array}{l}\text { The results of the regression } \\
\text { shows that issuance of Islamic } \\
\text { bonds is positively correlated } \\
\text { with the liquidity of IB's. This } \\
\text { means that issuance of Islamic } \\
\text { bonds leads to increase in the } \\
\text { liquidity of the IB's of Pakistan. } \\
\text { It helps the banks to provide } \\
\text { liquidity. }\end{array}$ \\
\hline
\end{tabular}

\section{Conclusion}

This study examined the relationship between sukuk and the performance of the IB's of Pakistan by taking six full-fledged Islamic banks of Pakistan as a sample for the study. The time period of last ten years 2008-2017 has been considered for this study. The results reveal that issuance of sukuk has significant positive relationship among sukuk and liquidity while, a significant but negative correlation among sukuk and profitability of IB's of the Pakistan. Sukuk is a significantly important source to provide bank's liquidity. The findings of the study are significantly important for the policy makers of Islamic Banking system of Pakistan because a well-developed sukuk market may pose threats to the profitability of IB's because an increase in sukuk issuance adversely affects the bank's profitability. The findings have contributed to the existing literature of (Islamic bonds) sukuk in a way that this research is the first study which have investigated the relationship between sukuk and IB's of Pakistan.

\section{References}

Ahmad, N., Daud, S. N., \& Kefeli, Z. "Economic Forces and the Sukuk Market Procedia”, in Social and Behavioral Sciences (2012): 127 - 133.

Ahmed, E. R., Islam, M. A., Yousif, T. T., \& Alabdullah,’Islamic Sukuk: Pricing Mechanism and Rating" in Researchgate (2014).

Akhtar, D. S. “Pakistan's Islamic Banking Sector Review 2003 to 2007”, Report by Islamic Banking Department, State Bank of Pakistan (2007). 
ljtihad: Jurnal Wacana Hukum Islam dan Kemanusiaan, Volume 19, No. 1, Juni 2019: 53-66

Alam, N., Hassan, M. K., \& Haque, M. A. "Are islamic bonds different from conventional bonds? International evidence from capital market tests", in Borsa Istanbul Review (2013): 22-29.

Alvi, M. I., Rufai, D. A., Dadabhoy, M. I., Khan, M. G., Naseer, M. U., Naseer, M. B., et al., "A comprehensive study of the Global Sukuk Market", IIFM (2014).

Bibi, S., \& Mazhar, F. 'Determinants of bank's profitability \& liquidity and the role of BASEL III in islamic \& conventional banking sector of pakistan: A case study of NBP" in The Economics and Finance Letters, Vol. 6, No.1 (2019): 40-56.

Braima, B. H. "Impact of Islamic Securitization (Sukuk) on Islamic Banks Liquidity Risk in Light of Basel III Requirements", in Journal of Finance \& Banking Studies,Vol. VI,No.1 (2017): 85-100.

Elhaj, M. A., Muhamed, N. A., \& Ramli, N. M.’'The Influence of Corporate Governance, Financial Ratios, and Sukuk Structure on Sukuk Rating”, in Procedia Economics and Finance, Vol. 31 (2015): 62-74.

Gitman, L. J., \& Zutter, C. J. Principles of Managerial Finance, 13th ed.,2018.

Khan, F. A., \& Siddiqui, D. A. "Islamic (Sukuk) vs. Conventional Financing: Analysis of Profitability", in International Journal of Experiential Learning \& Case Studies, Vol.3, No. 2 (2018): 246-257.

Lahsasna, A., Hassan, M. K., \& Ahmad, R. "Introduction to Sukuk. Forward Lease Sukuk in Islamic Capital Markets", in Palgrave Macmillan, Cham (2018).

Mohamed, H. H., Masih, M., \& Bacha, O. I.'Why do issuers issue Sukuk or conventional bond? Evidence from Malaysian listed firms using partial adjustment models", in Pacific-Basin Finance Journal, Vol.34 (2015): 233-252.

Nagano, M. "Sukuk issuance and information asymmetry: Why do firms issue sukuk?" in Pacific Basin Finance Journal,Vol. 42 (2016): 142-157.

Razak, S. S., Saiti, B., \& Dinc, Y. "The contracts, structures and pricing mechanisms of Sukuk: A critical assessment”, in Borsa Istanbul Review, Vol.1, No. 13 (2018).

Reuters, T. "Liquidity Management Through SUKUK Innovative Solutions", Report by The Thomson Reuters (2016). 
An Investigation of the Relationship between Sukuk and the Performance of banks...(Sitara Bibi)

Said, A. "Does the Use of Sukuk (Islamic bonds) Impact Islamic Banks Performances? A Case Study of Relative Performance during 2007-2009”, in Middle Eastern Finance and Economics No.12 (2011): 65-76.

Sekaran, U. Research methods for business. New York, USA: John Wiley \& Sons., 4th edition ed., Vol. 652003.

Smaoui, H., \& Khawaja, M. “The Determinants of Sukuk Market Development”, in Emerging Markets Finance and Trade, Vol. 53,No. 7 (2016): 1501-1518.

Smaoui, H., Mimouni, K., \& Temimi, A. "Sukuk, Banking System, and Financial Markets: Rivals or Complements?”, in Economics Letters (2017): 62-65.

Vishwanth, S., \& Azmi, S. "An Overview of Islamic Sukuk Bonds", in The Journal of Structured Finance Vol. 14, No. 4 (2009): 58-67.

Yesuf, A. J. "A Comparative Analysis of Sukuk and Conventional Bonds. Istanbul, Turkey", in The Springer International Publishing Switzerland (2016): 417-438.

Zawya, T. R. "Sukuk perceptions and forecast study 2014", in The Thomson Reuters Zawya, Dubai (2013).

Zulkhibri, M. "A synthesis of theoretical and empirical research on sukuk", in Borsa Istanbul Review, Vol. 15, No. 4 (2015): 237-248. 
